\title{
Pancreatic cystosis in cystic fibrosis
}

\author{
Helen Burt, ${ }^{1}$ Savvas Andronikou, ${ }^{2,3}$ Simon Langton-Hewer ${ }^{3}$
}

${ }^{1}$ Department of Clinical Radiology, University Hospitals Bristol NHS Foundation Trust, Bristol, UK

${ }^{2}$ University of Bristol, Bristol, Bristol, UK

${ }^{3}$ Bristol Royal Hospital for Children, Bristol, Bristol, UK

\section{Correspondence to}

Dr Helen Burt,

helenburt@doctors.org.uk

Accepted 19 February 2016

\section{DESCRIPTION}

A 17-year-old boy was diagnosed with cystic fibrosis at age 6 years. Genetic analysis revealed homozygous $\Delta \mathrm{F} 508$ mutations.

His first abdominal ultrasound was performed in March 2012 as part of the annual cystic fibrosis review. This demonstrated an echogenic pancreas but no other abnormality. Subsequent sonographic review demonstrated multiple anechoic lesions of varying sizes in the head of the pancreas, with posterior acoustic shadowing (figure 1).

An MR scan performed in March 2015 demonstrated multicystic transformation of the entire pancreas with no normal parenchymal tissue visible and no pancreatic duct dilation. This was most clearly demonstrated on T2-weighted HASTE FS sequences (figures 2 and 3 ). The largest cyst

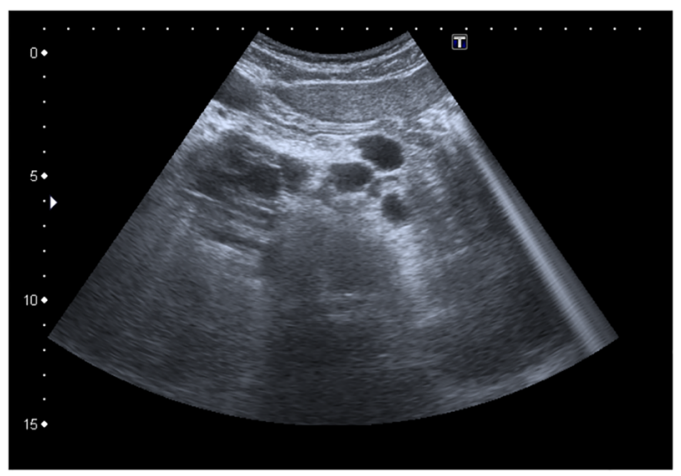

Figure 1 Transverse ultrasound through the head of the pancreas.

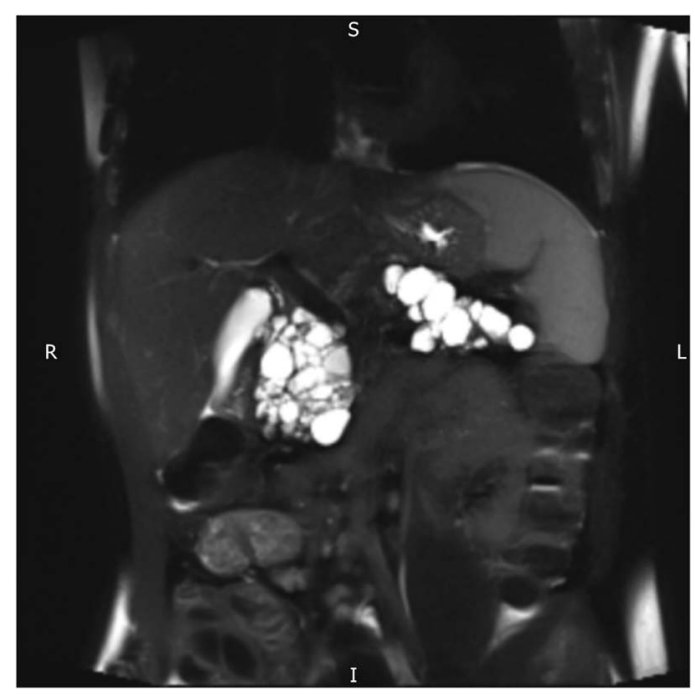

Figure 2 Coronal T2-weighted HASTE FS sequence through the pancreas.

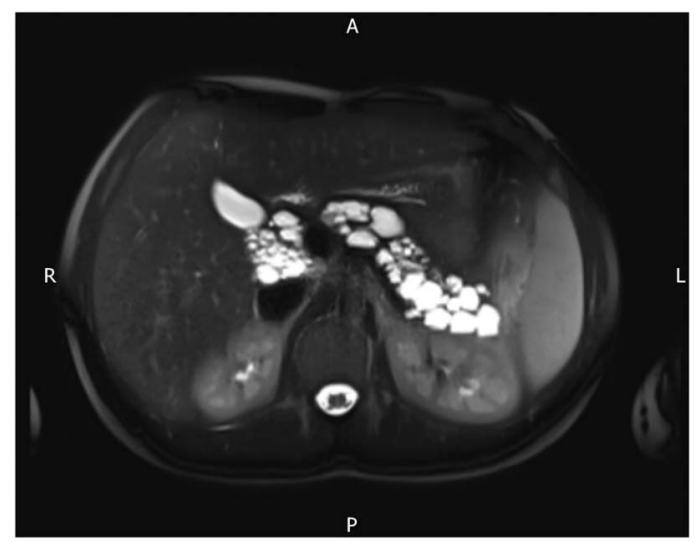

Figure 3 Axial T2-weighted HASTE FS sequence through the pancreas.

measured $2.5 \mathrm{~cm}$. The liver, gallbladder, spleen and kidneys were normal.

These features are in keeping with pancreatic cystosis, a rare benign complication of cystic fibrosis typically seen during the second decade of life. Histologically, pancreatic cystosis is a true cystic lesion lined by epithelium, with little to no pancreatic tissue between cysts. Although microscopic pancreatic cysts are common in cystic fibrosis, pancreatic cystosis results in macroscopic cysts ranging from 1.5 to $12 \mathrm{~cm}$. The cysts result from maintained secretory function despite ductal obstruction. ${ }^{1}$

This condition may present with abdominal pain, postprandial fullness and nausea caused by mass effect or haemorrhage into the cysts. ${ }^{1}$ Asymptomatic cases have been reported, and annual abdominal ultrasound conducted as part of ongoing monitoring may increase the diagnosis of this condition. The cysts have no known malignant potential, and intervention with its consequent risks should be avoided.

\section{Learning points}

- Annual review abdominal ultrasound should be followed up by MR scanning if cystic abnormalities are demonstrated within the pancreas.

- Classic radiographic appearances of cystic fibrosis are important to recognise to avoid unnecessary surgical procedures, which carry significant risk.

Contributors $\mathrm{HB}$ drafted the case history and images with annotations. SA revised the draft paper and images. SL-H suggested the case and revised the draft paper. 
Competing interests None declared.

Patient consent Obtained.

Provenance and peer review Not commissioned; externally peer reviewed.

\section{REFERENCE}

1 Freeman AJ, Giles HW, Nowicki MJ. Image of the month. Pancreatic cystosis complicating cystic fibrosis. Clin Gastroenterol Hepatol 2010;8:e18-9.

Copyright 2016 BMJ Publishing Group. All rights reserved. For permission to reuse any of this content visit http://group.bmj.com/group/rights-licensing/permissions.

BMJ Case Report Fellows may re-use this article for personal use and teaching without any further permission.

Become a Fellow of BMJ Case Reports today and you can:

- Submit as many cases as you like

- Enjoy fast sympathetic peer review and rapid publication of accepted articles

- Access all the published articles

- Re-use any of the published material for personal use and teaching without further permission

For information on Institutional Fellowships contact consortiasales@bmjgroup.com

Visit casereports.bmj.com for more articles like this and to become a Fellow 